\title{
WHAT HAVE WE LEARNT ABOUT BOARD GENDER DIVERSITY AS A BUSINESS STRATEGY?. THE APPOINTMENT OF BOARD SUB-COMMITTEES
}

\begin{abstract}
This article examines whether board gender diversity influences the voluntary formation of its Board Sub-committees. Board gender diversity has been measured as a proportion and with Blau's index. The results show that independent female directors on a board are positively associated with the likelihood of voluntarily setting up all or some of the Committees and a Supervision and Control Committee. The presence of executive female directors on boards negatively influences the probability of forming all or some of the Committees, an Executive Committee and a Supervision and Control Committee. The percentage of shares held by female directors has a positive effect on the voluntary creation of an Executive Committee. The findings also report that women directors and institutional female directors do not contribute to the voluntary creation of Board Sub-committees. The results show that the demand for internal control mechanism as Board Sub-committees, depends on the female directorship on boards.
\end{abstract}

Key words: Board gender diversity, business strategy, female directors, board sub-committees, voluntary creation

JEL: D71, G32, G34, M14 


\section{Introduction}

Past research has considered Board Sub-committees as a relevant mechanism of corporate governance since they may reduce agency costs (Ngoc Bich Tao and Marion Hutchinson 2013) and protect shareholders' interests (J. Richard Harrison 1987). Nevertheless, corporate governance literature has paid little attention to the influence of board gender diversity on the voluntary creation of Board Subcommittees.

Past research focused on corporate governance, management and gender diversity literature (see e.g., Renée B. Adams and Daniel Ferreira 2009; Sabina Nielsen and Morten Huse 2010) evidenced that gender diversity may affect the functioning and efficiency of corporate boards and committees. Previous research supports the hypothesis that board gender diversity improves the decision-making process of the board of directors (BD's) (Ronald C. Anderson, David M. Reeb, Arun Upadhyay, and Wanli Zhao 2011), enhances corporate governance control, as women directors are considered to be stricter monitors, and reduces malpractice (Joe Ueng, Daryl Koehn, and Ching Liang Chang 2009), among other things, which mitigates agency conflicts (C. Francoeur, Labelle, R. and B. SinclairDesgnané 2008). In addition, women directors are usually given riskier tasks than their men colleagues, and they outperform male board members (Michelle K. Ryan and S. Alexander Haslam 2007) since they foster good corporate practice (Zena Burgess and Phyllis Tharenou 2002). In this sense, Glass, Cook and Ingersoll (2016) provide evidence that companies with women leathering teams are more effective than other firms at pursuing corporate social responsibility strategies. Therefore, given the importance of women on boards in allocating capital to corporations, their role in firm corporate governance (Kevin Campbell and Antonio Mínguez-Vera 2008; Siri Terjesen, Ruth Sealy and Val Singh 2009), and the fact that previous research fails to identify the impact that female directors on boards have on the voluntary setting up of Board committees, an understanding of how gender diversity on corporate boards affects the voluntary formation of Board Sub-committees is undoubtedly needed. Thus, the aim of this study is to analyse the effect of board gender diversity on the voluntary setting up of Board Sub-committees.

Our research contributes to the corporate governance literature in several ways. First, we demonstrate that the demand for Board Sub-committees can vary depending on the structure of a Spanish Board's gender diversity. Specifically, our results show that one way in which women directors might play a role in monitoring management is through affecting the demand for control mechanisms, such as Board Sub-committees. Thus, we provide evidence that some characteristics of women directors, such as independence and ownership, may be useful for stakeholders, such as financial information users or shareholders, by enhancing the demand for Board Sub-committees, which suggests that female directors who are in a position to exert significant influence may increase the voluntary formation of Board Subcommittees. Second, we find evidence of substitutive effects between an Executive Committee and executive female directors on BDs, which suggests that Board Sub-committees, in general, and an Executive Committee, in particular, should not be considered in isolation. In sum, these results suggest that a one-size-fits-all solution for the creation of Board Sub-committees might not be optimal, as different firms face different incentives in composing their BD's.

The structure of this paper is as follows. Section 2 presents the institutional setting while Section 3 detailed the existing literature. Section 4 describes the empirical design and Section 5 reports the results. And finally, Section 6 provides concluding remark.

\section{Institutional Setting}

Spanish corporate governance system provides an opportunity to investigate the effect of board gender diversity on the voluntary setting up of Board Sub-committees, since it is characterised by the presence of a few large shareholders, weak investor protection, market control less active in comparison to Anglo-Saxon markets, high ownership concentration and a one-tier board system (all directors, nonexecutives and executives make up one board). Accordingly, this high ownership concentration acts as a legal control that influences Spanish corporate governance (Thomas Kirchmaier and Jeremy Grant 2005). These features are the board of directors' prevalent mechanism of control, as is the presence as directors of large block-holders, who are known as institutional directors. These directors play a 
significant role, because they have an important position on boards to represent the interests of large shareholders and institutional investors (Kirchmaier and Grant 2005). Accordingly, Spain is the European country with the highest presence of institutional investors on the boards of large firms (Alberto De Miguel, Julio Pindado, and Chabela De La Torre 2004), in contrast with the AngloAmerican context, where it is less common for institutional investors to be appointed as directors on a board.

In this context, Spain has published a set of codes of Corporate Governance in order to improve the confidence and transparency of the markets and to protect the wealth of minority shareholders. In this line, these codes recommended the establishment of Board Committees to perform tasks that are complementary to those of the BD. In this line, The Aldama Report (2003) recommended the creation of an Executive Committee, a Nomination and Compensation Committee and a Strategy and Investment Committee, also emphasising the creation of an Audit Committee, which is mandatory for listed firms. However, the CUBG (2006) omitted the Strategy and Investment Committee that drove the Aldama Report (2003), as the skills developed by this Committee were typical of the BD. It recognised the usefulness that a Corporate Governance Committee has for some firms, but generally, did not consider the need to recommend its creation. According to the Audit Committees, the Law on Measures to Reform the Financial System (LMRFS) of 2002 obliged listed firms to establish Audit Committees, with the objective of reviewing the financial statements of the firms before forwarding them to the BD and, therefore, they ceased to be a recommendation for listed firms and became an obligation.

Moreover, it is noteworthy that the sustained socio-economic changes in Spain in recent years have increased gender diversity on BD's. This increase was enhanced by the implementation of the Conthe Code (2006), and its proposals are intended to support a female presence. However, it was the implementation of Act 3/2007 of 22 March, for Effective Equality between Women and Men (LOIMH), Article 75, which frames the regulation of the appointment of men and women on BDs in an equitable form. In fact, the LOIMH (2007) recommended that Spanish boards of listed companies reached a gender quota of $40 \%$ by 2015 (a detailed analysis of gender quotas for BDs in several countries can be found in Siri Terjesen, Ruth V. Aguilera and Ruth Lorenz 2015). The Conthe Code was updated in 2015 , which suggests listed firms to reach a gender quota of $30 \%$ by 2020 . According to Heidrick and Struggles (2014) survey, the proportion of women directors on Spanish listed firm's boards has enhanced from $9 \%$ in 2011 to $13 \%$ in 2013.

\section{Literature review and hypotheses}

Agency theory posits that the separation between the ownership (principal) and control of a firm (agent) generates information asymmetries between the parties, because of the difficulty that owners face in assessing the behaviour of managers (Michael C. Jensen and William H. Meckling 1976). Therefore, firms have increased the demand for internal and external controls in order to reduce information asymmetry and agency costs. In this line, corporate governance literature shows that BD's is a crucial mechanism based on the premise that the characteristics of the board members determine the board's ability to monitor and control managers, provide information and counsel to managers, monitor compliance with applicable laws and regulations, and link the corporation to the external environment (David A. Carter, Betty J. Simkins, and W. Gary Simpson 2010). Thus, the BD is the main internal mechanism for resolving agency conflicts within the firm (Michael C. Jensen 1993), focusing principally on monitoring management team behaviour (Benjamin E. Hermalin and Michael S. Weisbach 1991). However, firms demand control mechanisms other than the BD, such as Board Subcommittees (also known as Board Committees), in order to reduce agency costs and information asymmetries, as well as to help it carry out its activities efficiently and independently (Harrison 1987). In this vein, authors such as Hugh D. Sherman, Roger J. Kashlak, and Maheshkumar P. Joshi (1998), among others, found that the major decisions made by BDs came from Board Sub-committees. The firm director of Roebuck and Firm noted in 1999 that firms are run primarily by their committees. Harrison (1987) demonstrated that the Control Committees were important management mechanisms for BDs to independently perform oversight functions. Audra L. Boone and J. Harold Mulherin (2012) showed that the creation of Board Sub-committees increased oversight functions and, thus, reduced agency 
problems. P. Wolnizer (1995) demonstrated that the principal operations performed by Board Subcommittees were the controlling and monitoring of the development and subsequent disclosure of accounting information. In a similar manner, Ruigrok et al. (2006) showed that the delegation of functions by the BD to Sub-committees increased the quality of the activities of the BD. Christian Laux and Volker Laux (2009) revealed that the Delegate Committees, at times, worked independently in order to achieve the objectives set by the corporate governance codes. However, sometimes, a single committee performed the combined functions of various committees.

Academic research has failed to show a relationship between board gender diversity and the demand for control mechanisms such as Board Sub-committees.

Female directors on corporate boards might act as a control mechanism over managers by supervising board duties and, consequently, agency costs arising from the separation of ownership and management could be reduced (Francoeur et al. 2008; Adams and Ferreira, 2009; David. A. Carter, Frank D'Souza, Betty J. Simkins, and W. Gary Simpson 2010) by demanding the formation of control mechanisms such as Board Sub-committees. Thus, female directors may monitor management more effectively than men directors (Bin Srinidhi, Ferdinand A. Gul, and Judy Tsui 2011). In this line, agency theory posits that board gender diversity may increase its effectiveness because women directors increase board independence (Carter et al. 2010), their perspectives are more wide-ranging and their decision-making processes are more extensive and, as a result, this may also lead to higher demands for control mechanisms. In the same vein, Nanette Fondas and Susan Sassalos (2000) indicated that women tend to have higher expectations regarding their responsibilities as directors, which may induce them to use more effort on their tasks.

Women on corporate boards lead to a greater diversity of knowledge and skills (Ruigrok et al. 2006; Nielsen and Huse 2010; Lucas-Pérez et al. 2014), and tend to increase the innovation activities for the companies (Horbach and Jacob, 2018) and provide different perspectives and opinions, which influences democratic decision-making (Elizabeth Webb 2004; Nielsen and Huse 2010). Authors like Pierpaolo Parrotta and Nina Smith (2013) and Alexa A. Perryman, Guy D. Fernando, and Arindam Tripathy (2016) report that women directors on boards are more risk averse in decision making, more conservative than men and less overconfident in their decision-making (Michael Dowling and Zakaria Ali Aribi 2013).

Thus, these perspectives seem to support the view that women directors on boards are more likely to demand control mechanisms. Consequently, we predict that female directors on BD's may have a positive effect on the demand for corporate governance mechanisms such as Board Sub-committees. Therefore, it is expected that, as the presence of women directors on BDs increases, the likelihood of the creation of Board Sub-committees will be greater, as female directors on BDs will demand more control mechanisms with which to exercise greater supervision and monitoring of both the management team and other members of the $\mathrm{BD}$, making better decisions that positively impact shareholders.

Hence, we posit the following hypothesis:

Hypothesis 1: Women directors on Boards are positively associated with the voluntary creation of Board Sub-committees.

Agency theory also argues that independent directors on boards act as good monitors for shareholders' interests, reducing agency problems and opportunistic conducts (Ruigrok et al. 2006; Christopher S. Armstrong, John E. Core, and Wayne R. Guay 2014). Thus, independent directors may improve the decision-making process and enhance the supervision over management (Jensen and Meckling 1976; Eugene F. Fama and Michael C. Jensen 1983). In this line, independent members of corporate boards will support the creation of Board Sub-committees, as such Committees may reduce information asymmetries between directors and enhance the confidence of the owners and investors in the firms. Past research reports that independent directors on boards increase the voluntary creation of Audit Committees (María Consuelo Pucheta-Martínez and Cristina De Fuentes-Barbera 2008), Risk Management Committees (Puan Yatim 2010), Oversight Committees (Julie Cotter and Mark Silvester 2003) and Board Sub-committees (Henry Huang, Gerald J. Lobo, and Jian Zhou 2009), among others. 
Building on cognitive psychology, sociology, economic and management literature, and focusing on gender diversity on corporate boards, authors such as Carter et al. (2003) support the idea that board gender diversity increases board independence, because directors with more traditional backgrounds do not ask the questions that would be asked by directors of a different gender, ethnicity or cultural background. Chi-keung Man and Brossa Wong (2013) posit that women directors can develop trust leadership, which requires managers to share information, and they are more likely to be risk-averse to fraud and opportunistic earnings management. In this line, other studies (Terjesen et al. 2009) also suggest that women directors can monitor managers' and CEOs' behaviour better and more effectively than male directors (Carter et al. 2003) through holding more informed discussions, having better communication skills, featuring better independent thinking, serving on monitoring-related committees, such as an Audit Committee, Nominating Committee or Corporate Governance Committee, and increasing board attendance, among other things, which is critical to check opportunistic activities and provide better control over management.

The assumed benefits of improved independence on corporate boards stems from the belief that independent directors are better monitors of management than inside directors (Mark L. DeFond and Jere R. Francis 2006). Thus, combining independence and the qualities of women directors, in comparison to their male counterparts, a positive influence of independent female directors on the setting up of Board Sub-committees would be expected, because they would have more freedom to demand them. Consequently, according to the previously discussed views, we predict that, as independent women directors on BDs increase, the greater is the likelihood of establishing Board Subcommittees, as this will allow them to conduct more comprehensive control over the management of the firm. In this sense, Francoeur et al. (2008) also suggest that incorporating independent female directors on BDs will allow better exercise of the supervision and control functions.

Hence, we posit our hypothesis in the following manner:

Hypothesis 2: Independent women directors on Boards are positively associated with the voluntary creation of Board Sub-committees

Executive directors on corporate boards provide only a restricted amount of information to nonexecutive directors in order to prevent stakeholders from obtaining all the information (Armstrong et al. 2014). The dominance of executive directors results in weak control mechanisms within the management structure, because they may have incentives to align with management in order to maximise their value and/or their own wealth at the expense of shareholders (Messod D. Beneish 2001). Executive directors on BDs also provide knowledge about the inner workings of the firm because of their relationships within the company, and they possess confidential information about the company (Eugene CM Cheng and Stephen M. Courtenay 2006). In this vein, Barry Baysinger and Robert E. Hoskisson (1990) argue that executive directors on BDs have more information and knowledge with which to evaluate strategic decisions.

Academic literature shows the negative impact of executive directors on BDs on financial disclosure (Cheng and Courtenay 2006), firm performance (Yu Liu, Zuobao Wei, and Feixue Xie 2014) and business failure (Hwa-Hsien Hsu and Chloe Yu-Hsuan Wu 2014), among other things. In the same vein, Emiliano Ruíz-Barbadillo, Estíbaliz Biedma-López, and Nieves Gómez-Aguilar (2007) demonstrate that executive directors on BDs increase management dominance over the board and, therefore, these directors are less likely to support the voluntary formation of Board Sub-committees, because these control mechanisms may monitor management actions.

Cognitive psychology, sociology and management literature posits that females are generally more riskaverse, more conservative and behave more ethically than males (Leora F. Klapper and Simon C. Parker 2011; Parrotta and Smith 2013; Bill Francis, Iftekhar Hasan, John Chool Park, and Qiang Wu. 2014; Perryman et al. 2016), which may influence corporate decisions and enhance the demand for control mechanisms. Kris Hardies, Ann Jorissen, and Parichart Maneemai (2014) find that women directors feel that there is more need for planning and are less overconfident than males, negatively impacting on firm performance. Contrary to this evidence, other papers (K. V. Petrides and Adrian Furnham 2006) report that there are no significant differences in the behaviors of male and female executives, and there are 
many similarities in the specific skills displayed by them, such as risk taking, as well as in the managerial roles performed. In the same vein, Gary N. Powell (1990) does not report evidence to support differences in executive men and women's task-oriented and people-oriented behaviour and their leadership styles.

According to previous arguments and evidence, female executive directors are likely to behave the same as male executives and, therefore, both executive women and men directors will align with management, as suggested by the academic literature (Beneish 2001). Thus, we predict that executive female directors on BDs decrease the probability of the voluntary creation of Board Sub-committees, as these committees involve more supervision and control of executive functions and management and, as a result, they will be reluctant to demand control mechanisms.

Hence, we posit our hypothesis in the following manner:

Hypothesis 3: Executive female directors on the Board of Directors are negatively associated with the voluntary creation of Board Sub-committees

According to agency theory, institutional directors will act independently from the insider directors and will act as good monitors to protect the shareholders' interests, mitigating agency problems between shareholders and managers (Hsu and $\mathrm{Wu}$ 2014). Institutional investors have greater expertise and resources in companies and, therefore, they have strong incentives to monitor managers (Hsu and $\mathrm{Wu}$ 2014). Some investigations support this thesis, as authors such as Wan Nordin Wan-Hussin (2009) reports that institutional directors reduce fraudulent accounting practices, increase corporate transparency and publish unbiased or less biased information, among other things. Consequently, this argument exposes a positive relationship between institutional directors on BDs and the voluntary formation of Board Sub-committees, because they play a complementary role in governance mechanisms.

However, contrary to this argument, another research (Raj Varma 2001) demonstrates that institutional directors are passive, and their role of monitoring managers is ineffective, because they prefer not to actively monitor the managers of a company in which they have invested, due to a conflict of interest arising from their existing business relations with the company (Pascal Frantz and Norvald Instefjord 2009), and because of their relatively myopic goals (institutional investors focus on short-term corporate performance) (Brian J. Bushee 1998), because of the free-rider problem (Anat R.Admati, Paul Pfleiderer, and Josef Zechner 1994) or because they do not have the capability (William Taylor 1990). In this line, John Pound (1993) shows that institutional shareholders empathise with the entrenched managers and vote for them. Consistent with these views, John Pound (1988) posits that institutional investors may align themselves with incumbent managers due to strategic alliances or existing relationships between them and, then, this leads to a decline in corporate monitoring. Accordingly, these arguments support a negative relationship between institutional directors and the setting up of Board Sub-committees, because institutional investors may cooperate with managers and enjoy the private benefits of control or preserve their business relations with their firms and, as a consequence, they are less motivated to monitor their governance. Additionally, institutional investors may entrench themselves and, therefore, achieve absolute control of the companies and extract private benefits, negatively impacting corporate monitoring. Consistent with this idea, Karen Van Nuys (1993) demonstrates that institutional directors on BDs support managers' decisions and collude with management.

Female directors, according to agency perspective, may act as a mechanism to control managers (Fama and Jensen 1983; Carter et al. 2003; Adams and Ferreira 2009), which may mitigate agency costs (Francoeur et al. 2008; Adams and Ferreira 2009). Prior research (Hang Dong 2014) provides evidence that institutional female directors may improve managerial monitoring because they improve firm performance, which is considered to be a financial mechanism of managerial discipline. Hence, the combination of gender diversity and institutional directors on BDs may increase the voluntary formation of Board Sub-committees. Nevertheless, other studies show that institutional female directors on BDs may not have the time or expertise to act as effective monitors and, thus, they could increase agency costs (Pound 1988; Phillip J. McKnight and Charlie Weir 2009). Accordingly, institutional female 
directors may use their aptitudes for their private benefit and align themselves with managers, reducing the voluntary creation of Board Sub-committees (Elizabeth Carson 2002).

In consequence, based on the above heterogeneous arguments, we hypothesise that institutional female directors may be negative or positively associated with the voluntary formation of Board Subcommittees, because they may demand more control mechanisms in order to exert more direct control over the management team, reducing information asymmetries and, as a consequence, agency costs (R. Aggarwal, Isil Erel, Miguel Ferreira, Pedro Matos 2011). But, the opposite may be also expected, according to prior literature.

Thus, we posit our hypothesis in the following manner:

Hypothesis 4: Institutional female directors on Boards of Directors are positive or negatively associated with the voluntary creation of Board Sub-committees

Ownership structure can reduce agency costs by actively monitoring (Neal M. Stoughton and Josef Zechner 1998) and intervening in the major decisions of the company (McConnel and Servaes 1990).

Jensen and Meckling (1976) used an agency framework to argue that, when corporate insiders (managers and board members) have a significant ownership stake, managerial incentives are more closely aligned with those of shareholders. Furthermore, when board members control a significant stake in the firm, they have a greater incentive to be effective monitors of managerial activity (William O. Brown and Michael T. Maloney 1999), and they also will make decisions consistent with maximising shareholders' wealth (Jensen and Meckling 1976), because that will maximise their own wealth. Thus, increases in the percentage of stock owned by board members should make them more sensitive to monitor unethical and opportunistic behaviors due to the negative impact that they may have on shareholders' interests; consequently, board members with ownership will be more likely to demand the setting up of Board Sub-committees. Therefore, board members' ownership serves as an important means of controlling agency problems. In this vein, prior research (M. Ameziane Lasfer 2006) shows that management ownership causes a greater alignment of interests between owners and managers, reducing agency problems.

Focusing on agency theory, women directors may make existing control mechanisms over managers stronger, because women directors increase board independence, and they are inclined to ask many questions (Carter et al. 2010). Thus, women directors on BDs may monitor management more effectively than men directors (Srinidhi et al. 2011) because their perspectives are more wide-ranging and their decision-making process is more extensive and, as a result, this may also lead to a higher demand for control mechanisms. Stakeholder theory posits that female directors will defend the interests of all stakeholders, avoiding problematic confrontations and providing different opinions and perspectives to board discussions, as well as more responsive policies. In addition, females behave more ethically than men in a business context (Helena Isidro and Márcia Sobral 2015) and are less likely to engage in unethical behaviour (Maria L. Roxas and Jane Y. Stoneback 2004). Thus, women on corporate boards will be more proactive about avoiding unethical behaviours. These theses support the view that female directors on BDs with shares will have the potential to help align the incentives of shareholders and managers though their impact on the voluntary formation of Board Sub-committees.

Therefore, based on the above arguments, we posit that the proportion of shares held by women directors encourages the demand for control mechanisms, and they may be positively associated with the voluntary formation of Board Sub-committees.

Hence, we posit our hypothesis in the following manner:

Hypothesis 5: The percentage of shares held by female directors on a Board of Directors is positively associated with the voluntary creation of Board Sub-committees

\section{Empirical Design}

\subsection{Sample}

The initial sample of this study consists of all non-financial firms listed on the Madrid Stock Exchange during 2004-2011. Financial firms have been excluded from the sample because they comply with particular accounting rules. The information used for this analysis was obtained from the public records 
of the Spanish Securities Market Committee (CNMV), the SABI database and the official websites of firms, while corporate governance information was collected from the annual corporate governance reports.

We built an unbalanced panel of 910 firm-year observations. Nevertheless, the estimations based on unbalanced panels are as reliable as those based on balanced panels (Manuel Arellano 2003).

\subsection{Variables}

The dependent variable (CDCA) will take the value 1 if the BD has voluntarily constituted all or some of the Committees recommended by the Codes of GCG (Executive Committee and Oversight and Control Committee: Nomination and Remuneration Committee and/or Compliance Committees or Corporate Governance) and 0, otherwise. The Audit Committee is not studied in this work, because it is a Board Sub-committee that is mandatory, rather than voluntary. Moreover, we also study how gender diversity in BDs can influence the voluntary creation of an Executive Committee, on the one hand, and some or all of the Committees for Oversight and Control, on the other. Thus, this paper tests three models. In Model 1, the dependent variable CDCA analyses all Committees recommended by the CGG, taking the value 1 if the BD has voluntarily created all or some of the Board Sub-committees and 0, otherwise. In Model 2, the dependent variable CDCA (named CDCA1) takes the value 1 if the BD has voluntarily established an Executive Committee and 0, otherwise. Finally, in Model 3, the dependent variable CDCA (named CDCA2) takes the value 1 if the BD has voluntarily established a Committee for Oversight and Control: a Nomination and Remuneration Committees and/or the Compliance Committee or Corporate Governance and 0, otherwise.

The independent variables about board gender diversity (women, independent women, institutional women and executive women) have been calculated in two ways: (1) as percentage or proportion, instead of absolute value, because they have much more explicative and comparative power than absolute numbers, and (2) using the Peter Michael Blau's index (1977). We define the percentage of female directors on BDs as MCA, and it is calculated as the ratio between the total number of women who make up the BD and the total number of members on the BD. The MICA variable represents the percentage of independent women on BDs, and it is calculated as the ratio between the total numbers of independent women on BDs and the total number of independent members on BDs. The variable MECA represents the percentage of executive women on BDs, and it is calculated as the ratio between the total number of executive women directors on BDs and the total number of executive directors on BDs. The percentage of institutional female directors on BDs is defined as MDCA, and it is calculated as the ratio between the total number of institutional female directors on BDs and the total number of institutional directors on BDs. In addition, and in line with previous studies (Campbell and MínguezVera 2008; Toyah Miller and María del Carmen Triana 2009), board gender diversity (women directors, independent female directors, executive female directors and institutional female directors) is also measured with Blau's (1977) index of heterogeneity. Blau's index has been frequently used and noted as an appropriate measure of board gender diversity for categorical variables (David A.Harrison and $\mathrm{H}$. Sin 2006). Blau's index of heterogeneity is calculated as $\left(1-\sum \mathrm{p}_{i}^{2}\right)$, where $\mathrm{p}_{i}$ is the proportion of group members in each of the í number of categories. The range of the index is dependent upon the number of categories, where the number ranges from 0 to (i-1)/í. Thus, Blau's index can range from 0 , when there is only one gender on the board, to 0.50 , when there are equal numbers of men and women on the board. Therefore, using Blau's index, we define MCA Blau Index as Blau's index of women/men directors on BDs, MICA_Blau Index as Blau's index of women/men independent directors on BDs, MECA_Blau Index as Blau's index of women/men insider or executive directors on BDs and MDCA_Blau Index as Blau's index of women/men institutional directors on BDs. The variable ACCWOM defines the percentage of shares held by women directors on BDs, and it is calculated as the percentage of shares held by women directors on BDs.

We control for a number of factors supported by previous evidence that can impact on the voluntary establishment of Board Sub-committees. TAMCA is the board size and is calculated as the total number of members on the BD. REUNCA is the activity of the board of directors, measured as the total number of meetings of the BD. TAMEMPR is the natural logarithm of total assets and is a measure of firm size. 
ANTEMPR is calculated as the logarithm of the difference between the year of establishment of the firm and the observation year, and represents the firm's age. CEO duality is defined as DPC, which is calculated as a dummy variable that takes the value 1 if one person holds both positions as chairman of the BD and CEO and 0, otherwise. BIGFOUR is calculated as a dummy variable that takes the value 1 if the firm is audited by a major accounting firm (Ernst \& Young, PriceWaterHouseCoopers, Deloitte and KPMG) and 0, otherwise. LEV is the financial leverage variable, calculated as the ratio of book value of debt to total assets. Finally, OWNCON is the ownership concentration and is measured as the proportion of shares held by shareholders holding at least 5\% of the firm's stock. In Table 1 we provide all the variables used and the expected sign for each one.

Insert Table 1 about here

\section{Results}

\subsection{Descriptive Statistics}

Table 2 presents mean value, median, standard error, and percentiles 25 and 75 of the main variables. Insert Table 2 about here

As shown in Table 2, the average percentage of women on BDs is 7\%. Moreover, it is observed that, of all women who are on BDs, $6.40 \%$ are independent directors, $1.90 \%$ are executive directors and $8.1 \%$ are institutional directors. In addition, we appreciate that the average Blau's index of women/men on BDs is 0.11, the Blau's index of women/men independent directors on BDs is 0.075, the Blau's index of women/men executive directors on BDs is 0.022 , and the Blau's index of women/men institutional directors on BDs is 0.082 , where the highest possible Blau's index gender diversity score was 0.5 , if the board had equal numbers of men and women on the board and the ownership of the firm held by women directors on BDs is 2.2. Also, it can be seen that a BD, on average, is formed of 10.50 members and meets 9.57 times a year. The average size of firms in the sample is 13.00 (logarithm of total assets), the average age of firms is 3.55 years, and finally, the level of leverage is $54 \%$. Moreover, the statistics reveal that $84 \%$ of companies have voluntarily constituted all or some of the Board Sub-committees, $36 \%$ created an Executive Committee, and 83\% voluntarily formed a Committee for Supervision and Control. Furthermore, in $25 \%$ of the firms in the sample, the chairman of the BD is also the CEO, and $86 \%$ of firms are audited by one of the big auditing firms. Finally, the data show that ownership concentration is, on average, $41.30 \%$.

\subsection{Regression Results}

In Table 3, we show the results of the logistic regression when measuring board gender diversity as a percentage or proportion. As can be observed, we have built three models. In Model 1, we examined whether the BD has voluntarily formed all or some of the Board Sub-committees. In Model 2, we examined whether the BD has voluntarily established an Executive Committee, and in Model 3, we observed whether the BD has voluntarily created a Committee for Supervision and Control, that is, if they have formed Appointments and Remuneration and/or Compliance or Corporate Governance Committees. The Chi-square test shows that all three models are statistically significant at the $1 \%$ level. Insert Table 3 about here

The results in Table 3 show that, for Model 1, the variable percentage of women directors on the BD (MCA_Proportion) has a positive sign, but it is not statistically significant; hence, we reject the first hypothesis. Thus, we conclude that the percentage of women directors on BDs has no impact on the formation of all or some of the Board Sub-committees. This result could be explained by the fact that the percentage of female directors on BDs is not an essential feature for the firms listed on the Madrid Stock Exchange, as evidenced by Elena Merino-Madrid, Montserrat Manzaneque-Lizano, and Regino Banegas-Ochovo (2009), so that the percentage of female directors on BDs is not a relevant factor in the establishment of all or some of the Board Sub-committees. The variable percentage of independent female directors on BDs (MICA_Proportion) shows a positive sign, as predicted, and is statistically significant at the 1\% level (see Yusuf Ekrem Akbas, Mehmet Senturk, and Canan Sancar 2013). Hence, we cannot reject the second hypothesis. This permits us to conclude that the presence of independent women directors on BDs increases the probability of the voluntary formation of all or some of the 
Board Sub-committees. Furthermore, the variable percentage of women executive directors on BDs (MECA Proportion) is statistically significant and presents the expected sign. Thus, we cannot reject the third hypothesis. This finding suggests that a higher percentage of executive female directors on BDs has a negative effect on the voluntary setting up of all or some of the Board Sub-committees. The variable percentage of institutional female directors (MDCA_Proportion) presents the expected sign, but it is not statistically significant. Therefore, we reject the fourth hypothesis. This result is in line with those reported by Wan-Hussin (2009) and Hsu and $\mathrm{Wu}$ (2014), who showed that the presence of institutional female directors on BDs brings transparency and a greater ability to report and monitor the management team and, therefore, the creation of Board Sub-committees is not necessary. This finding suggests that there is a substitution effect between the percentage of institutional women directors on BDs and the voluntary creation of Board Sub-committees. The variable percentage of shares held by women directors (ACCWOM) is not statistically significant. Thus, the fifth hypothesis has to be rejected.

Regarding the control variables, we note that the variables BD size (TAMCA), BD activity (REUNCA), firm size (TAMEMPR) and audit firm (BIGFOUR) have a positive sign, as predicted, and are statistically significant. In addition, the variable duality of Chairman and CEO has a positive sign, contrary to what was expected, and is statistically significant.

The results of Model 2 demonstrate that the variables percentage of executive women directors (MECA_Proportion) and the percentage of shares held by women directors on BDs present a negative and positive sign, respectively, as expected, and are statistically significant. Hence, we cannot reject the third and fifth hypotheses. Therefore, we can conclude that, as the percentage of shares held by female directors on BDs increases, the greater is the probability of the creation of an Executive Committee on the $\mathrm{BD}$, while a higher percentage of female executive directors on the BD reduces that likelihood. Carson (2002) obtained similar results, demonstrating the positive relationship between the shareholdings of directors and the formation of a Remuneration Committee. R. A. G. Monks and N. Minow (2004) argued that high equity ownership by directors is an important factor in increasing the willingness of directors to monitor. The remainder of the independent variables are not statistically significant.

The control variables BD size, firm size, firm age, and CEO duality show the expected signs and are statistically significant. Thus, we can conclude that the probability of creating an Executive Committee on the BD will increase in larger and older firms, whose BDs are large, while this probability is reduced with CEO duality. The other control variables are not significant.

Model 3 shows that the variables percentage of independent female directors on BDs and percentage of executive female directors on BDs offer a positive and negative sign, respectively, as expected, and are statistically significant. Hence, we cannot reject the second and third hypotheses. Therefore, according to these results, we can conclude that the percentage of independent women directors on BDs increases the voluntary establishment of a Committee for Supervision and Control, while the percentage of executive female directors decreases this likelihood. The rest of the independent variables are not statistically significant. With respect to the control variables, we obtained similar results to Model 1. BD size and activity, firm size and auditing firms are statistically significant and show a positive sign, as predicted. Thus, these findings suggest that there is a greater likelihood of the creation of a voluntary Supervision and Control Committee as BD size and activity, firm size and audits of a firm by one of the big audit firms increase. Moreover, the variable CEO duality has a positive sign, contrary to our expectations, but is statistically significant. Accordingly, this result suggests that CEO duality encourages the voluntary creation of Committees for Supervision and Control. In the same vein, Gerald Chau and Patrick Leung (2006) also documented that CEO duality increases the likelihood of the creation of a Committee for Supervision and Control. The other control variables are not statistically significant.

In Table 4, we show the results of the logistic regression when measuring board gender diversity with Blau's index. As can be observed, we have built three models, as in Table 3. The Chi-square test shows that all three models are statistically significant at the $1 \%$ level.

Insert Table 4 about here 
As observed in Table 4, for Model 1, only the variable representing independent female directors on boards with the Blau index shows the expected sign and is statistically significant. Thus, this finding supports the second hypothesis. The rest of the independent variables are not statistically significant. Consistent with Model 1 in Table 3, where board gender diversity is measured with proportions, the control variables board size and activity, firm size, duality and auditing firm are statistically significant. Thus, we cannot reject the second hypothesis, and the remainder of the hypotheses cannot be supported by the findings. Our results suggest that independent women directors on boards measured with the Blau index increase the likelihood of the voluntary creation of all or some of the Board Sub-committees. As in Model 2, when board gender diversity is measured as a proportion, executive female directors on BDs and the percentage of shares held by female directors on BDs provide the predicted sign and are statistically significant. These findings support the third and fifth hypotheses, and therefore, they suggest that the percentage of executive women directors on BDs is negatively associated with the likelihood of setting up an Executive Committee, while a higher percentage of shares held by female directors on BDs has a positive effect on the voluntary creation of an Executive Committee. The rest of the independent variables are not statistically significant. The control variables show the same direction and significance as in Model 2, when board gender diversity is measured as a percentage.

Finally, in Model 3, in comparison to board gender diversity proportion, only the independence of female directors on BDs presents the expected sign and is statistically significant. Thus, our results support the second hypothesis, but not the remainder of the hypotheses. Therefore, the findings suggest that independent female directors on BDs are positively associated with the probability of the voluntary formation of a Committee for Supervision and Control.

To test for multicollinearity, we calculated the Spearman correlation coefficients for all of the variables included in the model. Table 5 presents the results for the correlation matrix. An analysis of this table shows that the correlation between some pairs of variables is statistically significant at $1 \%, 5 \%$ or $10 \%$ levels. These results are consistent with previous studies concerning the voluntary formation of Board Sub-committees (Pucheta-Martínez and De Fuentes-Barbera 2008). However, none of the correlation coefficients are high enough $(>80)$ to cause significant problems of multicollinearity (see Deborah Archambeault and F. Todd DeZoort 2001), except for the pairs MCA_P/MCA_B, MICA_P/MICA_B, MECA_P/MECA_B and MDCA_P/MDCA_B (we do not include them together in the regressions), so that multicolinearity should not be a concern.

Insert Table 5 about here

\section{Conclusions}

The aim of this study is to determine whether gender diversity in BDs of firms listed on the Madrid Stock Exchange influences the voluntary formation of Board Sub-committees. Our study provides evidence that independent women directors in decision-making bodies of firms encourage the delegation by BDs of functions to Board Sub-committees, which play a crucial role in monitoring management. In addition, a high percentage of women executive directors on BDs could be seen as a substitute for an Executive Committee, and to avoid duplication of functions, they would be more reluctant to create this Committee. On the other hand, the percentage of shares held by female directors (proportion and Blau's index models) has a positive effect on the voluntary creation of an Executive Committee since the ownership structure encourages the voluntary setting-up of control mechanisms such as Board Sub-committees (Stoughton and Zechner 1998). Finally, the findings report that women directors (without distinguishing the type of directorship) and institutional female directors (proportion and Blau's index) do not contribute to the voluntary creation of all or some of the Board Subcommittees or to the formation of an Executive Committee and a Committee for Supervision and Control. One explanation for the lack of impact of women directors could be that, when they are analysed as a whole, this directorship is composed of different kinds of directors, and therefore, it is possible that opposite effects compensate, and consequently, the whole effect is null. Focusing on the lack of effect of institutional female directors, this could be due to institutional female directors may align with management, and therefore, it is less likely that these directors demand control mechanisms such as Board Sub-committe (Andres Almazán, Jay C. Hartzell, and Laura T. Starks 2005) 
This analysis has several implications. Our findings are relevant for Spanish policymakers who prescribe actions regarding the presence of women in decision-making bodies of companies, particularly in top positions, regarding corporate governance structures to guarantee the protection of the stakeholders, especially shareholders, and regarding the voluntary setting-up of Board Subcommittees. Independent female directors on boards and ownership by women directors encourage the demand for Board Sub-committees; therefore, this result supports Act3/2007 (The Equality Law), which encourages Spanish boards of listed companies to reach a gender quota of $40 \%$ by 2015 . Thus, our evidence supports the legislative initiative to establish quotas for women in corporate governance bodies of firms (e.g., as set by the European Union Justice Committee and the Financial Reporting Council at the end of 2010 and the Spanish Act 3/2007 of 22 March, for Effective Equality between Women and Men), based on the premise that some characteristics of gender diversity in Spanish BDs (independence and ownership by women directors) encourage the voluntary creation of Board Subcommittees. This point of view is supported by Mehdi Nekhili and Hayette Gatfaoui (2012). In addition, the results are also important for researchers who examine the role of women in decision-making bodies and their influence on different outcomes of the companies, and specifically, for those authors who show that women in decision-making bodies have an important influence on the fostering of good corporate practice (Burgess and Tharenou 2002), among other things.

Our results suggest that women in top positions are neither "walk-on actors" nor "trophy wives", as previous research, which does not find a relationship between women in executive positions and financial reporting quality or dividend policy, may suggest. Thus, these findings provide evidence of the need to continue researching issues about women in corporate governance, especially in the international context, as a comparison of our results with other legal, cultural, professional and regulatory environments would enrich the debate about gender diversity in corporate governance. In short, both policymakers and researchers should no longer consider gender diversity as a whole, because the composition of gender diversity has various implications for the voluntary creation of Board Sub-committees.

\section{References}

Act 3/2007 of 22 March, for Effective Equality between Women and Men (LOIMH) (BOE n. 71 de 23/3/2007)

Adams, Renée B., and Daniel Ferreira. 2009. "Women in the boardroom and their impact on governance and performance." Journal of Financial Economics, 94(2): 291-309.

Admati, Anat R., Paul Pfleiderer, and Josef Zechner. 1994. "Large shareholder activism, risk sharing, and financial market equilibrium." Journal of Political Economy, 102(6): 1097-1130.

Aggarwal, R., Isil Erel, Miguel Ferreira, Pedro Matos. 2011. "Does governance travel around the world? Evidence from institutional investors." Journal of Financial Economics, 100(1): 154-181.

Akbas, Yusuf Ekrem, Mehmet Senturk, and Canan Sancar. 2013. "Testing for Causality between the Foreign Direct Investment, Current Account Deficit, GDP and Total Credit: Evidence from G7." Panoeconomicus, 60(6): 791-812.

Aldama Report. 2003. Informe de la Comisión Especial para el Fomento de la transparencia y la Seguridad en los Mercados Financieros y en las Sociedades Cotizadas. Madrid: Ministerio de Economía y Hacienda.

Almazan, Andres, Jay C. Hartzell, and Laura T. Starks. 2005. "Active institutional shareholders and costs of monitoring: Evidence from executive compensation." Financial Management, 34(4): 534.

Anderson, Ronald C., David M. Reeb, Arun Upadhyay, and Wanli Zhao. 2011. "The economics of director heterogeneity." Financial Management, 40(1): 5-38.

Archambeault, Deborah, and F. Todd DeZoort. 2001. "Auditor opinion shopping and the Audit Committee: an analysis of suspicious auditor switches." International Journal of Auditing, 5(1): $33-52$.

Arellano, Manuel. 2003. Panel data econometrics. Oxford: Oxford University Press. London. 
Armstrong, Christopher S., John E. Core, and Wayne R. Guay. 2014. "Do independent directors cause improvements in firm transparency?" Journal of Financial Economics, 113(3): 383-403.

Baysinger, Barry, and Robert E. Hoskisson. 1990. "The composition of Boards of Directors and strategic control: effects on corporate strategy." Academy of Management Review, 15(1): 72-87.

Beneish, Messod D. 2001. "Earnings management: A perspective." Managerial Finance, 27(12): 3-17.

Blau, Peter Michael. 1977. Inequality and heterogeneity: A primitive theory of social structure. New York: Free Press.

Boone, Audra L., and J. Harold Mulherin. 2012. "How do corporate Boards balance monitoring and advising? The Situational Use of Special Committees in Corporate Takeovers, The Situational Use of Special Committees in Corporate Takeovers" (November 27, 2012), 1-54. Available at SSRN: https://ssrn.com/abstract=1783064 or http://dx.doi.org/10.2139/ssrn.1783064

Brown, William O., and Michael T. Maloney. 1999. "Exit, voice, and the role of corporate directors: Evidence from acquisition performance.” Available at SSRN 160308.

Burgess, Zena, and Phyllis Tharenou. 2002. "Women Board Directors, characteristics of the few." Journal of Business Ethics, 37(1): 39-49.

Bushee, Brian J. 1998. "The influence of institutional investors on myopic R\&D investment behaviour." The Accounting review, 73(3): 305-333.

Campbell, Kevin, and Antonio Mínguez-Vera. 2008. "The influence of gender on Spanish Boards of Directors: an empirical analysis", WP-EC 2007-2008, Instituto Valenciano de Investigaciones Económicas, 1-30.

Carter, David. A., Frank D'Souza, Betty J. Simkins, and W. Gary Simpson. 2010. "The gender and ethnic diversity of US boards and board committees and firm financial performance." Corporate Governance: An International Review, 18(5): 396-414.

Carter, David A., Betty J. Simkins, and W. Gary Simpson. 2003. "Corporate Governance, Board diversity, and firm value." The Financial Review, 38(1): 33-53.

Carson, Elizabeth. 2002. "Factors associated with the development of Board Sub-Committees." Corporate Governance: An International Review, 10(1): 4-18.

Chau, Gerald, and Patrick Leung. 2006. "The impact of Board composition and family ownership on Audit Committee formation: evidence from Hong Kong." Journal of International Accounting, Auditing and Taxation, 15(1): 1-15.

Cheng, Eugene CM, and Stephen M. Courtenay. 2006. "Board composition, regulatory regime and voluntary disclosure." The International Journal of Accounting, 41(3): 262-289.

Cotter, Julie, and Mark Silvester. 2003. "Board and monitoring committee independence." Abacus, 39(2): 211- 232.

De Miguel, Alberto, Julio Pindado, and Chabela De La Torre. 2004. "Ownership structure and firm value: New evidence from Spain.” Strategic Management Journal, 25(12): 1199-1207.

DeFond, Mark L., and Jere R. Francis. 2005. "Audit research after sarbanes-oxley."Auditing: A Journal of Practice \& Theory, 24(s-1), 5-30.

Dong, Hang. 2014. "Essays on Mutual Fund Strategies and Investor Characteristics." PhD Dissertion. Universidad Carlos III de Madrid.

Dowling, Michael, and Zakaria Ali Aribi. 2013. "Female directors and UK company acquisitiveness." International Review of Financial Analysis, 29, 79-86.

Fama, Eugene F., and Michael C. Jensen. 1983. "Separation of ownership and control." Journal Law Economics, 26(2): 301-325.

Financial Reporting Council. 2010. UK corporate governance code 2010.

Fondas, Nanette, and Susan Sassalos. 2000. "A different voice in the boardroom: how the presence of women directors affects board influence over management." Global Focus, 12(2): 13-22.

Francis, Bill, Iftekhar Hasan, John Chool Park, and Qiang Wu. 2014. "Gender differences in financial reporting decision making: Evidence from accounting conservatism." Contemporary Accounting Research, 32(3): 1285-1318.

Francoeur, C., Labelle, R.and B. Sinclair-Desgnané. 2008. "Gender diversity in Corporate Governance and top management." Journal of Business Ethics, 81(1): 83-95. 
Frantz, Pascal, and Norvald Instefjord. 2009. "Large shareholders and corporate governance." Economics of Governance, 10(4): 297-321.

Glass, C., Cook, A., \& Ingersoll, A. R. 2016. "Do women leaders promote sustainability? Analyzing the effect of corporate governance composition on environmental performance." Business Strategy and the Environment, 25(7): 495-511.

Huang, Henry, Gerald J. Lobo, and Jian Zhou. 2009. "Determinants and accounting consequences of forming a Governance committee: evidence from the United States." Corporate Governance: An International Review, 17(6): 710-727.

Hardies, Kris, Ann Jorissen, and Parichart Maneemai. 2014. "On the Presence and Absence of CEO Gender Effects on Management Control Choices: An Empirical Investigation." Available at SSRN: https://ssrn.com/abstract=2496613 or http://dx.doi.org/10.2139/ssrn.2496613

Harrison, David A., and H. Sin. 2006. "What is diversity and how should it be measured?" In Konrad, A. M., Prasad, P. and Pringle, J. K. (Eds), Handbook of Workplace Diversity. London: Sage, 191216.

Harrison, J. Richard. 1987. "The strategic use of Corporate Board Committees." California Management Review, 30(1): 109-125.

Hermalin, Benjamin E., and Michael S. Weisbach. 1991. "The effect of Board composition and direct incentives in firm performance." Financial Management, 20(4): 101-112.

Heidrick \& Struggles. (2014). Towards dynamics governance 2014. European corporate governance report. Chicago, IL: Heidrick \& Struggles.

Hillman, Amy J., Albert A. Cannella Jr, and Ira C. Harris. 2002. "Women and racial minorities in the boardroom: how do directors differ?" Journal of Management, 28(6): 747-763.

Horbach, J., and Jacob, J. 2017. "The relevance of personal characteristics and gender diversity for (eco)-innovation activities at the firm-level: Results from a linked employer-employee database in Germany". Business Strategy and the Environment, First published: 22 February 2018.

Hsu, Hwa-Hsien, and Chloe Yu-Hsuan Wu. 2014. "Board composition, grey directors and corporate failure in the UK." The British Accounting Review, 46(3): 215-227.

Isidro, Helena, and Márcia Sobral. 2015. "The effects of women on corporate boards on firm value, financial performance, and ethical and social compliance." Journal of Business Ethics, 132(1): 119.

Jensen, Michael C. 1993. "The modern industrial revolution, exit, and the failure of internal control systems." The Journal of Finance, 48(3): 831-880.

Jensen, Michael C., and William H. Meckling. 1976. "Theory of the firm: managerial behaviour, agency costs and ownership structure." Journal of Financial Economics, 3(4): 305-360

Klapper, Leora F., and Simon C. Parker. 2011. "Gender and the business environment for new firm creation." The World Bank Research Observer, 26(2): 237-257.

Kirchmaier, Thomas, and Jeremy Grant. 2005. "Corporate ownership structure and performance in Europe." European Management Review, 2(3): 231-245.

Lasfer, M. Ameziane. 2006. "The interrelationship between managerial ownership and Board structure." Journal of Business Finance and Accounting, 33(7-8): 1006-1033.

Laux, Christian, and Volker Laux. 2009. "Board Committees, CEO compensation, and earnings management." The Accounting Review, 84(3): 869-891.

Law 44/2002, of 22 of November, Law on Measures to Reform the Financial System (LMRFS)

Liu, Yu, Zuobao Wei, and Feixue Xie. 2014. "Do women directors improve firm performance in China?" Journal of Corporate Finance, 28: 169-184.

Lucas-Pérez, María Encarnación, Antonio Mínguez-Vera, Juan Samuel Baixauli-Soler, Juan Francisco Martín-Ugedo, and Gregorio Sánchez-Marín. 2014. "Women on the board and managers' pay: Evidence from Spain.” Journal of Business Ethics, 129(2): 265-280

Man, Chi-keung, and Brossa Wong. 2013. "Corporate governance and earnings management: A survey of literature." Journal of Applied Business Research, 29(2): 391-418. 
McKnight, Phillip J., and Charlie Weir. 2009. "Agency costs, corporate governance mechanisms and ownership structure in large UK publicly quoted companies: A panel data analysis." The Quarterly Review of Economics and Finance, 49(2): 139-158.

Merino-Madrid, Elena Montserrat Manzaneque-Lizano, and Regino Banegas-Ochovo. 2009. "Retribución y composición del Consejo de Administración. Evidencia empírica para las empresas cotizadas españolas." Pecvnia, 8: 203-234.

Miller, Toyah, and María del Carmen Triana. 2009. "Demographic diversity in the boardroom: Mediators of the board diversity-firm performance relationship." Journal of Management Studies, 46(5): 755-786.

Monks, R. A. G. and N. Minow. 2004. Corporate governance, 3rd edn. Madden, MA: Blackwell Publishing Ltd

Nekhili, Mehdi, and Hayette Gatfaoui. 2012. "Are demographic attributes and firm characteristics drivers of gender diversity? Investigating women's positions on French Boards of Directors." Journal of Business Ethics, 118(2): 1-23.

Nielsen, Sabina, and Morten Huse. 2010. "The contribution of women on Boards of Directors: going beyond the surface." Corporate Governance: An International Review, 18(2): 136-148.

Parrotta, Pierpaolo, and Nina Smith. 2013. "Female-Led Firms: Performance and Risk Attitudes." IZA Discussion Paper No. 7613. Available at SSRN: https://ssrn.com/abstract=2329083

Perryman, Alexa A., Guy D. Fernando, and Arindam Tripathy. 2016. "Do gender differences persist? An examination of gender diversity on firm performance, risk, and executive compensation." Journal of Business Research, 69(2): 579-586.

Petrides, K. V., and Adrian Furnham. 2006. "The role of trait emotional intelligence in a genderspecific model of organizational variables." Journal of Applied Social Psychology, 36(2): 552569.

Pound, John. 1988. "Proxy contests and the efficiency of shareholder oversight." Journal of Financial Economics, 20, 237-265.

Pound, John. 1993. "Rise of the Political Model of Corporate Governance and Corporate Control." New York University Law Review, 68, 1003.

Powell, Gary N. 1990. "One more time: do female and male managers differ?" Academy of Management Executive, 4(3): 68-75.

Pucheta-Martinez, Maria Consuelo, and Cristina De Fuentes-Barbera. 2008. "Determinantes de la formación voluntaria de Comités de Auditoría entre las empresas cotizadas." Moneda y Crédito, 227: 83-115.

Roxas, Maria L., and Jane Y. Stoneback. 2004. "The importance of gender across cultures in ethical decision-making." Journal of Business Ethics, 50(2): 149-165.

Ruigrok, Windfried, Simon Peck, Sabina Tacheva, Peder Greve, and Yan Hu. 2006. "The determinants and effects of Board Nomination Committees." Journal of Management and Governance, 10(2): 119-148.

Ruíz-Barbadillo, Emiliano, Estíbaliz Biedma-López, and Nieves Gómez-Aguilar. 2007. "Managerial dominance and Audit Committee independence in Spanish Corporate Governance." Journal of Management and Governance, 11(4): 331-352.

Ryan, Michelle K., and S. Alexander Haslam. 2007. "The glass cliff: Exploring the dynamics surrounding women's appointment to precarious leadership positions." Academy of Management Review, 32(2): 549-572.

Sherman, Hugh D., Roger J. Kashlak, and Maheshkumar P. Joshi. 1998. "The effect of the Board and Executive Committee characteristics on the degree of internationalization." Journal of International Management, 4(4): 311-335.

Srinidhi, Bin, Ferdinand A. Gul, and Judy Tsui. 2011. "Female directors and earnings quality." Contemporary Accounting Research, 28(5): 1610-1644.

Stoughton, Neal M., and Josef Zechner. 1998. "IPO-mechanisms, monitoring and ownership structure." Journal of Financial Economics, 49(1): 45-77. 
Tao, Ngoc Bich, and Marion Hutchinson. 2013. "Corporate governance and risk management: The role of risk management and compensation committees." Journal of Contemporary Accounting and Economics, 9(1): 83-99.

Taylor, William. 1990. “Can big owners make a difference?” Harvard Review, 68(5): 70-82.

Terjesen, Siri, Ruth Sealy, and Val Singh. 2009. "Women directors on corporate boards: A review and research agenda." Corporate Governance: An International Review, 17(3): 320- 337.

Terjesen, Siri, Ruth V. Aguilera, and Ruth Lorenz. 2015. "Legislating a woman's seat on the board: Institutional factors driving gender quotas for boards of directors." Journal of Business Ethics, 128(2): 233-251.

Ueng, Joe, Daryl Koehn, and Ching Liang Chang. 2009. "Relationships between director profile and restatements of suspect earnings." Journal of Business \& Economics Research, 7(4): 75-92.

Unified Code of Corporate Governance (CUBG). 2006. Informe del grupo especial de trabajo sobre buen gobierno de las sociedades cotizadas, Comité Conthe. Madrid

Van Nuys, Karen. 1993. "Corporate governance through the proxy process: evidence from the 1989 Honeywell proxy solicitation." Journal of Financial Economics, 34(1): 101-132.

Varma, Raj. 2001. "The role of institutional investors in equity financing and corporate monitoring." Journal of Business and Economic Studies, 7(1): 39-53.

Wan-Hussin, Wan Nordin. 2009. "The impact of family-firm structure and Board composition on Corporate transparency: evidence based on segment disclosures in Malaysia." The International Journal of Accounting, 44(4): 313-333.

Webb, Elizabeth. 2004. "An examination of socially responsible firms' board structure." Journal of Management and Governance, 8(3): 255-277.

Wolnizer, P. 1995. "Are Audit Committee red herrings.” Abacus, 31(1): 45-66.

Yatim, Puan. 2010. "Board structures and the establishment of a Risk Management Committee by Malaysian listed firms." Journal of Management and Governance, 14(1): 17-36. 


\begin{tabular}{|c|c|c|}
\hline Variable & Description & $\begin{array}{c}\text { Expected } \\
\text { Sign in the } \\
\text { three } \\
\text { models }\end{array}$ \\
\hline \multicolumn{3}{|c|}{ INDEPENDENT VARIABLES } \\
\hline MCA_Proportion & Number of women in $\mathrm{BD} /$ Total number of members in $\mathrm{BD}$ & + \\
\hline MCA_Blau Index & Blau's index of women/men directors in $\mathrm{BD}$ & + \\
\hline MICA_Proportion & $\begin{array}{l}\text { Number of independent women in } \mathrm{BD} / \text { Total number of independent } \\
\text { members in } \mathrm{BD}\end{array}$ & + \\
\hline MICA_Blau Index & Blau's index of women/men independent directors in BD & + \\
\hline MECA_Proportion & $\begin{array}{l}\text { Number of insiders women in BD/ Total number of insiders members in } \\
\mathrm{BD}\end{array}$ & - \\
\hline MECA_Blau Index & Blau's index of women/men insider directors in BD & - \\
\hline MDCA_Proportion & $\begin{array}{l}\text { Number of institutional women in } \mathrm{BD} / \text { Total number of institutional } \\
\text { members in } \mathrm{BD}\end{array}$ & $+/-$ \\
\hline MDCA_Blau Index & Blau's index of women/men institutional directors in BD & $+/-$ \\
\hline ACCWOM & Shares held by women of BD & + \\
\hline \multicolumn{3}{|c|}{ CONTROL VARIABLES } \\
\hline TAMCA & Total number of directors in $\mathrm{BD}$ & + \\
\hline REUNCA & Number of times BD meets per year & + \\
\hline TAMEMPR & Log of total assets (in thousands of Euros) & + \\
\hline ANTEMPR & Log of the difference between setting-up firm and observation year & $+/-$ \\
\hline DPC & $\begin{array}{l}\text { Dummy variable equals to } 1 \text { if the same person serves simultaneously as } \\
\text { CEO and President of the BD }\end{array}$ & - \\
\hline BIGFOUR & $\begin{array}{l}\text { Dummy variable equals to } 1 \text { if the firm is audited by one of the big } \\
\text { auditing firms }\end{array}$ & + \\
\hline LEV & Ratio of book value of debt over total assets & - \\
\hline OWNCON & $\begin{array}{l}\text { Proportion of shares held by shareholders holding at least } 5 \% \text { of the } \\
\text { firm's stock }\end{array}$ & - \\
\hline
\end{tabular}


Table 2 Main Descriptive Statistics

\begin{tabular}{|c|c|c|c|c|c|c|}
\hline \multicolumn{7}{|c|}{ a) Continuous Variables } \\
\hline Variables & $\mathrm{N}$ & Mean & Median & Std. Dev. & $\mathrm{P} 25$ & P75 \\
\hline MCA_Proportion & 910 & 0.070 & 0.000 & 0.090 & 0.000 & 0.111 \\
\hline MICA_Proportion & 910 & 0.064 & 0.000 & 0.150 & 0.000 & 0.000 \\
\hline MECA_Proportion & 910 & 0.019 & 0.000 & 0.090 & 0.000 & 0.000 \\
\hline MDCA_Proportion & 910 & 0.081 & 0.000 & 0.181 & 0.000 & 0.100 \\
\hline MCA_Blau Index & 910 & 0.113 & 0.000 & 0.137 & 0.000 & 0.197 \\
\hline MICA_Blau Index & 910 & 0.075 & 0.000 & 0.154 & 0.000 & 0.000 \\
\hline MECA_Blau Index & 910 & 0.022 & 0.000 & 0.096 & 0.000 & 0.000 \\
\hline MDCA_Blau Index & 910 & 0.082 & 0.000 & 0.151 & 0.000 & 0.117 \\
\hline ACCWOM & 910 & 0.022 & 0.000 & 0.089 & 0.000 & 0.006 \\
\hline TAMCA & 910 & 10.502 & 10.000 & 3.823 & 8.000 & 12.000 \\
\hline REUNCA & 910 & 9.577 & 9.000 & 5.045 & 7.000 & 12.000 \\
\hline TAMEMPR & 910 & 13.006 & 12.811 & 1.880 & 11.700 & 14.341 \\
\hline ANTEMPR & 910 & 3.553 & 3.690 & 0.952 & 2.944 & 4.174 \\
\hline LEV & 910 & 0.540 & 0.510 & 0.620 & 0.270 & 0.693 \\
\hline OWNCON & 910 & 0.413 & 0.403 & 0.282 & 0.151 & 0.633 \\
\hline \multicolumn{7}{|l|}{ b) Dummy Variables } \\
\hline & & & 0 & $\%(0)$ & 1 & $\%(1)$ \\
\hline CDCA & & & 144 & $16 \%$ & 766 & $84 \%$ \\
\hline CDCA1 & & & 586 & $64 \%$ & 324 & $36 \%$ \\
\hline CDCA2 & & & 154 & $17 \%$ & 756 & $83 \%$ \\
\hline $\mathrm{DPC}$ & & & 682 & $75 \%$ & 228 & $25 \%$ \\
\hline BIGFOUR & & & 127 & $14 \%$ & 783 & $86 \%$ \\
\hline
\end{tabular}

Mean, median, standard deviation and percentiles of the main variables. CDCA: dummy variable equal to 1 if the BD has established all or some of the Committees recommended by the Good Governance Code (CGG); CDCA1: dummy variable equal to 1 if the BD has established an Executive Committee; CDCA2: dummy variable equal to 1 if the BD has established a Supervision and Control Committee: a Nomination and Compensation Committee and/or a Compliance or Corporate Governance Committee; MCA_Proportion: Percentage of female directors on BD's; MICA_Proportion: Percentage of independent female directors on BD's; MECA_Proportion: Percentage of executive female directors on BD's; MDCA_Proportion: Percentage of institutional female directors on BD's; MCA_Blau Index is the measure for women/men directors on board; MICA_Blau Index is the measure for independent women/men directors on board; MECA_Blau Index is the measure for executive women/men directors on board; MDCA_Blau Index is the measure for institutional women/men directors on board; ACCWOM: Percentage of shares held by women directors on BD's; TAMCA: BD size measured as the total number of directors in BD's; REUNCA: BD activity measured as the number of times that the BD meets per year; TAMEMPR: Firm size measured as the log of the total assets of the firm (in thousands of Euros); ANTEMPR: Firm age measured as the log of the difference between setting-up of the firm and observation year; DPC: Dummy variable equal to 1 if the same person serves simultaneously as CEO and Chairman on BD's; BIGFOUR: dummy variable equal to 1 if the company is audited by one of the big auditing firms; LEV: Leverage measured as book value of debt over total assets and OWNCON is the proportion of shares held by shareholders holding at least $5 \%$ of the firm's stock. 
Table 3 Results of Regression for Board of Directors (Gender diversity with proportions).

\begin{tabular}{|c|c|c|c|c|}
\hline & $\begin{array}{l}\text { Expected } \\
\text { Sign }\end{array}$ & $\begin{array}{c}\text { Model } 1 \\
\text { Parameters } \\
\text { estim. } \\
\text { (M.P.) }\end{array}$ & $\begin{array}{c}\text { Model } 2 \\
\text { Parameters } \\
\text { estim. } \\
\text { (M.P.) }\end{array}$ & $\begin{array}{c}\text { Model } 3 \\
\text { Parameters } \\
\text { estim. } \\
\text { (M.P.) }\end{array}$ \\
\hline MCA_Proportion & + & $\begin{array}{c}0.532 \\
(0.084)\end{array}$ & $\begin{array}{c}0.973 \\
(0.278)\end{array}$ & $\begin{array}{c}1.286 \\
(0.217)\end{array}$ \\
\hline MICA_Proportion & + & $\begin{array}{c}3.760 * * * \\
(0.599)\end{array}$ & $\begin{array}{c}0.029 \\
(0.008)\end{array}$ & $\begin{array}{c}3.439 * * * \\
(0.580)\end{array}$ \\
\hline MECA_Proportion & - & $\begin{array}{l}-1.723^{*} \\
(-0.274)\end{array}$ & $\begin{array}{c}-1.629 * * \\
(-0.466)\end{array}$ & $\begin{array}{l}-1.525^{*} \\
(-0.257)\end{array}$ \\
\hline MDCA_Proportion & $+/-$ & $\begin{array}{c}-0.510 \\
(-0.081)\end{array}$ & $\begin{array}{c}0.305 \\
(0.087)\end{array}$ & $\begin{array}{c}-0.581 \\
(-0.098)\end{array}$ \\
\hline ACCWOM & + & $\begin{array}{c}0.004 \\
(0.000)\end{array}$ & $\begin{array}{c}0.016 * * \\
(0.005)\end{array}$ & $\begin{array}{c}0.004 \\
(0.001)\end{array}$ \\
\hline TAMCA & + & $\begin{array}{c}0.091 * * * \\
(0.014)\end{array}$ & $\begin{array}{c}0.092 * * * \\
(0.026)\end{array}$ & $\begin{array}{c}0.096 * * * \\
(0.016)\end{array}$ \\
\hline REUNCA & + & $\begin{array}{c}0.102 * * * \\
(0.016)\end{array}$ & $\begin{array}{c}0.012 \\
(0.003)\end{array}$ & $\begin{array}{c}0.074 * * * \\
(0.012)\end{array}$ \\
\hline TAMEMPR & + & $\begin{array}{c}0.221 * * * \\
(0.035)\end{array}$ & $\begin{array}{c}0.250 * * * \\
(0.071)\end{array}$ & $\begin{array}{c}0.260 * * * \\
(0.043)\end{array}$ \\
\hline ANTEMPR & - & $\begin{array}{c}-0.033 \\
(-0.005)\end{array}$ & $\begin{array}{c}-0.140 * * * \\
(-0.040)\end{array}$ & $\begin{array}{c}-0.072 \\
(-0.012)\end{array}$ \\
\hline DPC & - & $\begin{array}{c}0.680 * * * \\
(0.108)\end{array}$ & $\begin{array}{l}-0.221^{*} \\
(-0.063)\end{array}$ & $\begin{array}{c}0.684 * * * \\
(0.115)\end{array}$ \\
\hline BIGFOUR & + & $\begin{array}{c}0.394 * * \\
(0.062)\end{array}$ & $\begin{array}{c}0.095 \\
(0.027)\end{array}$ & $\begin{array}{l}0.302^{*} \\
(0.050)\end{array}$ \\
\hline LEV & - & $\begin{array}{c}-0.030 \\
(-0.005)\end{array}$ & $\begin{array}{c}-0.149 \\
(-0.042)\end{array}$ & $\begin{array}{c}-0.035 \\
(-0.006)\end{array}$ \\
\hline OWNCON & - & $\begin{array}{c}0.001 \\
(0.000)\end{array}$ & $\begin{array}{c}-0.001 \\
(-0.000)\end{array}$ & $\begin{array}{c}0.002 \\
(0.000)\end{array}$ \\
\hline $\begin{array}{l}\text { Observations } \\
\chi^{2}\end{array}$ & & $\begin{array}{c}910 \\
270.710 * * *\end{array}$ & $\begin{array}{c}910 \\
264.020 * * *\end{array}$ & $\begin{array}{l}910 \\
272.610 * * *\end{array}$ \\
\hline
\end{tabular}


Table 4 Results of Regression for Board of Directors (Gender diversity with Blau's Index).

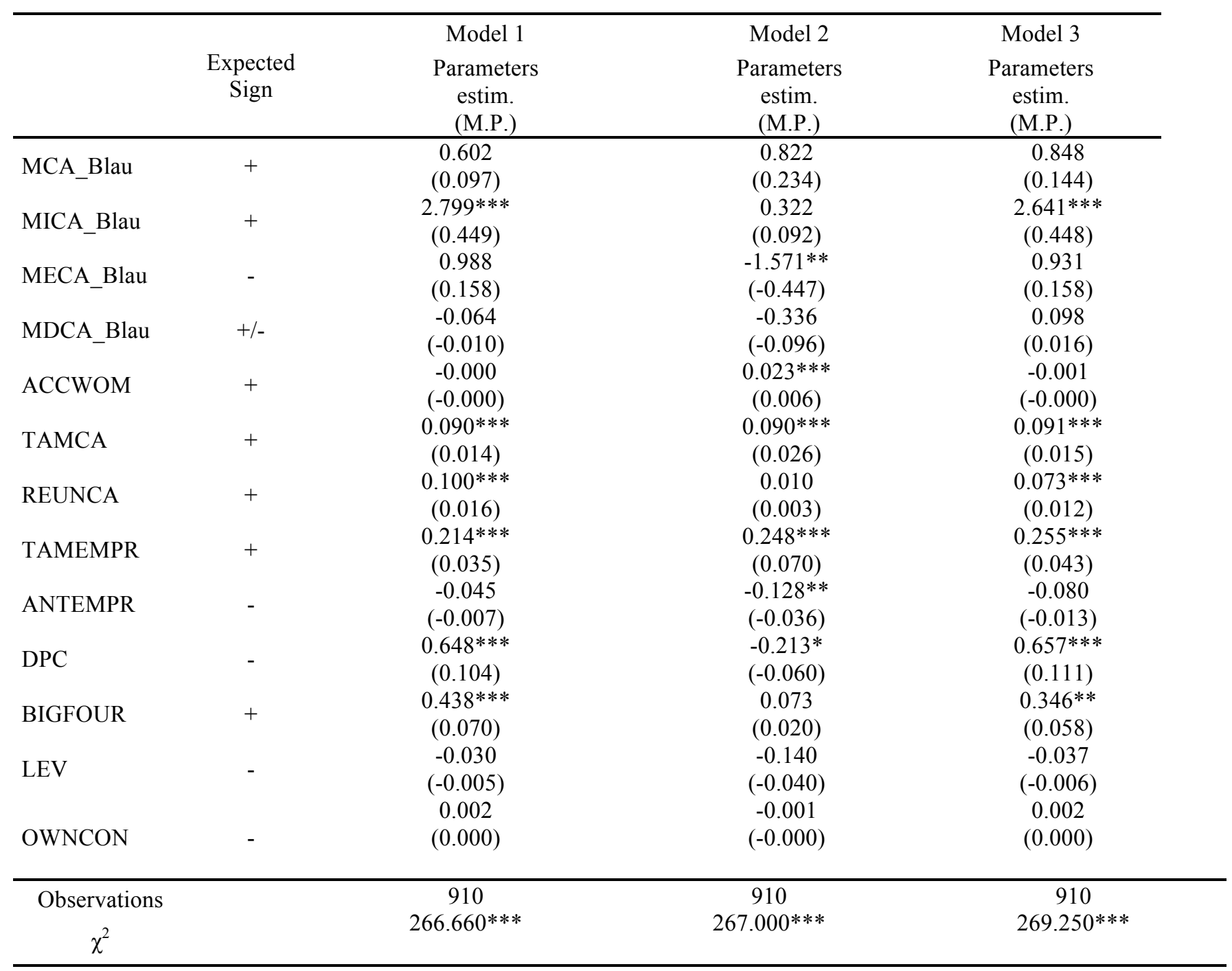


Table 5 Correlation Matrix.

\begin{tabular}{|c|c|c|c|c|c|c|c|c|c|c|c|c|c|c|c|c|c|c|c|}
\hline & $\mathrm{CDCA}$ & CDCA1 & $\mathrm{CDCA} 2$ & MECA_B & MDCA_B & MICA_B & MCA_B & MCA_P & MICA_P & MECA_P & MDCA_P & REMUCA & TAMCA & REUNCA & TAMEMPR & ANTEMPR & $\mathrm{DPC}$ & BIGFOUR & LEV \\
\hline CDCA1 & $0.322 * * *$ & & & & & & & & & & & & & & & & & & \\
\hline CDCA2 & $0.467 * * *$ & $0.280^{* * *}$ & & & & & & & & & & & & & & & & & \\
\hline MECA_B & 0.048 & $-0.072 * *$ & 0.054 & & & & & & & & & & & & & & & & \\
\hline MDCA_B & -0.042 & $-0.082 * *$ & $0.058^{*}$ & $\begin{array}{l}0.089 * * * \\
-0.105\end{array}$ & & & & & & & & & & & & & & & \\
\hline MICA_B & $0.193 * * *$ & $0.190 * * *$ & $0.197 * * *$ & $* * *$ & $-0.061 *$ & 0.494 & & & & & & & & & & & & & \\
\hline MCA_B & $0.170 * * *$ & $0.150 * * *$ & $0.188 * * *$ & $0.289 * * *$ & $0.560 * * *$ & $\begin{array}{l}* * * \\
0.498\end{array}$ & & & & & & & & & & & & & \\
\hline MCA_P & $0.120 * * *$ & $0.122 * * *$ & $0.139 * * *$ & $\begin{array}{l}0.318^{* * *} \\
-0.093\end{array}$ & $0.609 * * *$ & $\begin{array}{l}* * * \\
0.975\end{array}$ & $\begin{array}{l}0.926^{* * *} \\
0.510\end{array}$ & & & & & & & & & & & & \\
\hline MICA_P & $0.198 * * *$ & $0.175 * * *$ & $0.201 * * *$ & $* * *$ & -0.049 & $\begin{array}{l}* * * \\
-0.108\end{array}$ & $\begin{array}{l}* * * \\
0.294\end{array}$ & $0.515 * * *$ & & & & & & & & & & & \\
\hline MECA_P & -0.052 & $-0.078 * *$ & $-0.057 *$ & $0.973 * * *$ & $0.081 * *$ & $* * *$ & $\begin{array}{l}* * * \\
0.613\end{array}$ & $0.323 * * *$ & $-0.097 * * *$ & & & & & & & & & & \\
\hline MDCA_P & -0.005 & $0.085 * *$ & -0.022 & $0.093 * * *$ & $0.927 * * *$ & $\begin{array}{l}-0.035 \\
0.391\end{array}$ & $\begin{array}{l}* * * \\
0.425\end{array}$ & $0.665 * * *$ & $\begin{array}{l}-0.026 \\
0.385\end{array}$ & $0.085 * *$ & & & & & & & & & \\
\hline REMUCA & $0.163 * * *$ & $0.151 * * *$ & $0.144 * * *$ & $\begin{array}{l}0.024 \\
-0.134\end{array}$ & $0.150 * * *$ & $\begin{array}{l}* * * \\
0.200\end{array}$ & $\begin{array}{l}* * * \\
0.110\end{array}$ & $0.390 * * *$ & $\begin{array}{l}* * * \\
0.193\end{array}$ & $\begin{array}{l}0.019 \\
-0.141\end{array}$ & $0.155 * * *$ & & & & & & & & \\
\hline TAMCA & $0.325 * * *$ & $0.421 * * *$ & $0.336 * * *$ & $\begin{array}{l}* * * \\
-0.089\end{array}$ & $0.145 * * *$ & $\begin{array}{l}* * * \\
0.114\end{array}$ & $* * *$ & 0.053 & $\begin{array}{l}* * * \\
0.119\end{array}$ & $\begin{array}{l}* * * \\
-0.102\end{array}$ & $0.093 * * *$ & $0.169 * * *$ & & & & & & & \\
\hline REUNCA & $0.304 * * *$ & $0.184 * * *$ & $0.272 * * *$ & $* * *$ & -0.037 & $\begin{array}{l}* * * \\
0.207\end{array}$ & $\begin{array}{l}0.007 \\
0.102\end{array}$ & -0.000 & $\begin{array}{l}* * * \\
0.195\end{array}$ & $* * *$ & $-0.076 * *$ & $\begin{array}{l}0.115 * * * \\
0.2288\end{array}$ & $\begin{array}{l}0.232 \text { *** } \\
0.658\end{array}$ & & & & & & \\
\hline TAMEMPR & $0.385 * * *$ & $0.433 * * *$ & $0.400 * * *$ & $\begin{array}{l}-0.045 \\
-0.155\end{array}$ & $0.082 * *$ & $\begin{array}{l}* * * \\
-0.159\end{array}$ & $\begin{array}{l}* * * \\
-0.128\end{array}$ & $0.070 * *$ & $\begin{array}{l}* * * \\
-0.157\end{array}$ & $\begin{array}{l}-0.059 * \\
-0.167\end{array}$ & $0.065 * *$ & $* * *$ & $* * *$ & $0.293 * * *$ & & & & & \\
\hline ANTEMPR & -0.023 & -0.042 & -0.035 & $* * *$ & $0.069 * *$ & $* * *$ & $* * *$ & $-0.107 * * *$ & $* * *$ & $\begin{array}{l}* * * \\
0.086\end{array}$ & $0.066 * *$ & -0.003 & $0.078 * *$ & 0.025 & $0.119 * * *$ & & & & \\
\hline DPC & $0.135 * * *$ & -0.050 & $0.134 * * *$ & $0.093 * *$ & -0.063 & -0.053 & $\begin{array}{l}0.031 \\
0.090\end{array}$ & 0.031 & $\begin{array}{l}-0.055^{*} \\
0.094\end{array}$ & $* * *$ & -0.000 & -0.025 & $\begin{array}{l}-0.051 \\
0.289\end{array}$ & 0.051 & 0.022 & 0.006 & 0.168 & & \\
\hline BIGFOUR & $0.345 * * *$ & $0.161 * * *$ & $0.324 * * *$ & $0.068 * *$ & 0.040 & $\begin{array}{l}0.088 * \\
-0.080\end{array}$ & $* * *$ & $0.086 * * *$ & $\begin{array}{l}* * * \\
-0.008\end{array}$ & $0.071 * *$ & 0.017 & $0.129 * * *$ & $\begin{array}{l}* * * \\
0.188\end{array}$ & $0.242 * * *$ & $0.342 * * *$ & 0.020 & $\begin{array}{l}* * * \\
0.035\end{array}$ & & \\
\hline LEV & $0.077 * *$ & 0.054 & $0.080 * *$ & 0.017 & $0.127 * * *$ & $* *$ & $\begin{array}{l}0.029 \\
-\end{array}$ & 0.008 & $* *$ & 0.002 & $0.117 * * *$ & -0.002 & $* * *$ & $0.173 * * *$ & $0.357^{* * *}$ & $0.215 * * *$ & $* * *$ & 0.050 & \\
\hline OWCON & 0.016 & 0.035 & 0.028 & $0.068 *$ & -0.000 & -0.001 & $0.101 * * *$ & $-0.068 * *$ & -0.007 & $0.077 * *$ & -0.032 & -0.040 & 0.017 & $-0.081 * *$ & $0.172 * * *$ & 0.049 & -0.030 & 0.020 & 0.022 \\
\hline
\end{tabular}

